\title{
Epidemiology and Control of Citrus Greasy Spot in Different Citrus-Growing Areas in Florida
}

L. W. Timmer, Professor, University of Florida, Citrus Research and Education Center (CREC), Lake Alfred 33850; P. D. Roberts, Assistant Professor, University of Florida, Southwest Florida Research and Education Center, Immokalee 34142; H. M. Darhower and P. M. Bushong, Senior Biologists, University of Florida, CREC, Lake Alfred 33850; E. W. Stover, Assistant Professor, Indian River Research and Education Center, Ft. Pierce 34945; T. L. Peever, Assistant in Plant Pathology, University of Florida, CREC, Lake Alfred 33850; A. M. Ibáñez, Senior Biologist, University of Florida, CREC, Lake Alfred 33850

\begin{abstract}
Timmer, L. W., Roberts, P. D., Darhower, H. M., Bushong, P. M., Stover, E. W., Peever, T. L., and Ibáñez, A. M. 2000. Epidemiology and control of citrus greasy spot in different citrusgrowing areas in Florida. Plant Dis. 84:1294-1298.

Greasy spot, caused by Mycosphaerella citri, causes defoliation and yield losses on grapefruit in all areas of Florida, but is more severe in southwest Florida and the east coast than in central Florida. The amount of leaf litter, numbers of ascospores produced, and severity of greasy spot on trap plants were monitored throughout 1997 and 1998 in Immokalee (southwest Florida) and Lake Alfred (central Florida). Leaf litter and ascospore production were greatest from March to July in both locations, with little litter and few ascospores thereafter. Ascospore production occurred earlier in Immokalee than in Lake Alfred in both years. Disease on trap plants was moderate to severe throughout the year except from November to February. Large numbers of ascospores produced early in the year when conditions were less favorable resulted in the same disease severity levels as low numbers of ascospores produced later in the year when environmental conditions were favorable. Greater greasy spot severity in southwest Florida, compared with central Florida, is more likely due to higher rainfall and warmer winter temperatures than to differences in time of infection. Single annual copper fungicide applications were made each month from April to August in 1998 and 1999 in LaBelle (southwest Florida), Ft. Pierce (east coast), and Lake Alfred to determine the most effective time of application. Two two-spray treatments, May + July and June + August, were also evaluated in 1999. A single copper fungicide application in June provided the most consistently effective control across all locations. The June + August two-spray treatment was very effective in disease control, but usually no better than a well-timed single application.
\end{abstract}

Citrus greasy spot, caused by $\mathrm{Myco}$ sphaerella citri Whiteside, produces lesions on leaves that result in premature defoliation and a rind blemish on fruit, reducing the exterior quality and thus the marketability of the fruit. Greasy spot is most severe on grapefruit (Citrus paradisi Macf.) but affects most citrus. The major source of inoculum is ascospores produced from pseudothecia formed in decomposing leaf litter on the orchard floor (8). Low numbers of conidia are produced, but they are not an important source of inoculum (8).

Corresponding author: L. W. Timmer

E-mail: 1wt@lal.ufl.edu

Current address of T. L. Peever: Department of Plant Pathology, Washington State University, Pullman 99164.

Florida Agricultural Experiment Station Journal Series R-07597.

Accepted for publication 4 September 2000.

Publication no. D-2000-1016-02R

(C) 2000 The American Phytopathological Society
In Florida, the spring flush of growth and flowering occur from late February through early April. Additional flushes of growth occur sporadically during the summer rainy season from June to September. Grapefruit mature by October and are harvested through the following May. As originally described from studies in central Florida, greasy spot was essentially a monocyclic disease $(8,11,12)$. Greasy spot-affected leaves fell in late winter and early spring. Pseudothecia developed slowly in decomposing leaves during dry weather in spring in Florida. Thus, ascospore release often was delayed until the summer rains began. Ascospores deposited on the undersurface of the leaves germinated and grew epiphytically, and the fungus eventually penetrated through stomata.

Once infection occurred, the pathogen developed slowly. Symptoms from infection in the summer did not appear until November or December, and leaves did not usually fall until January or February.

Under these conditions, a single fungicide application made in June or July provided adequate disease control in central Florida $(9,14)$. The optimum time of appli- cation for maximum control varied slightly from year to year. In a long-term study from 1976 to 1989 in central Florida and east coast groves, peak ascospore release varied from as early as April in some years to as late as August in others (4). The best timing of single fungicide applications was about 20 to 30 days following peak ascospore releases when those peaks corresponded with warm, humid periods. Russo and Bistline (4) concluded that additional fungicide applications as early as April and as late as August-September may be necessary.

The geographic distribution of the Florida citrus industry and the cultural practices used have changed since Whiteside $(8,14)$ conducted his studies. After several severe freezes in the 1980s, the industry has moved south, with considerable growth in southwest Florida. Irrigation practices have also changed. In earlier years, many groves were not irrigated, and those that were irrigated had overhead sprinklers and were watered only once every 2 to 3 weeks. Currently, most groves have undertree microsprinklers and are irrigated 2 to 3 times per week. Most groves have discontinued use of cultivation and now apply herbicide for weed control in the tree rows. In this cultural system, leaves are never buried by cultivation and potential weed interference with ascospore dispersal is minimal. Earlier studies (5) indicated that these changes have resulted in a more prolonged period of infection, particularly in southwest Florida. As a result, growers now make additional fungicide applications for greasy spot control.

This study was undertaken to reassess the seasonal patterns of leaf litter accumulation, ascospore release, and infection by $M$. citri in central and southwest Florida to provide information for better timing of fungicide applications. Timing of fungicide applications was evaluated in the central, southwest, and east coast growing areas of Florida.

\section{MATERIALS AND METHODS}

Epidemiological studies. Study sites. Trap plant infection, the amount of leaf litter, ascospore count, and environmental data were collected in two mature groves 
of grapefruit during 1997 and 1998. One was located at the Citrus Research and Education Center in Lake Alfred in central Florida and the other at the Southwest Florida Research and Education Center near Immokalee in southwest Florida. At both sites, weeds were controlled under the trees by application of pre- and postemergence herbicides, and the vegetation between rows was mowed. Trees were irrigated by under-the-tree microsprinkler systems as needed. No fungicide applications were made during the course of the study at either site, but occasional insecticide or miticide sprays were applied. Leaf litter data were collected on four test trees at each site, two in each of two adjacent rows, and all test trees were located within $30 \mathrm{~m}$ of one another.

Trap plants. Rough lemon (C. jambhiri Lush.) trap plants were used to determine the severity of infection occurring during each 2-week period at both locations in the test. Seedlings were grown in the greenhouse as a single stem in 2.5-liter plastic pots in a soilless potting mix to a height of at least $1 \mathrm{~m}$. Prior to placement in the field, seedlings were pruned to a height of $0.7 \mathrm{~m}$, leaving about 20 to 30 mature leaves on each plant. Every 2 weeks year-round, six seedlings were placed at each site near the drip line of the test trees, and the previous set was removed. Seedlings were irrigated by drippers placed in each pot. Plants were positioned so that foliage was not wetted by the microsprinklers but was exposed to dew and rain.

After exposure in the field, potted seedlings were removed and placed in the greenhouse where the foliage was kept dry and symptom development monitored for 6 months. All new shoots were removed continually from trap plants, and ratings were made only on the mature leaves that had been exposed to inoculum in the field. After 6 months, greasy spot symptoms on the top 10 leaves of each plant were rated on a scale of $0=$ none, $1=1$ to $5 \%, 2=6$ to $10 \%, 3=10$ to $15 \%, 4=16$ to $20 \%$, and $5=>20 \%$ of the leaf surface area affected by the disease. Only actual lesion areas were considered in the ratings, and surrounding chlorotic areas were disregarded. Ratings were assigned to individual leaves by comparison with photographs of leaves whose lesion areas had been determined by computer-assisted image analysis. Leaves that had already fallen due to greasy spot at the time of assessment were assigned a rating of 6. Data presented are the average ratings of the six trap plants exposed during each 2-week period. Every 6 months, a set of nonexposed seedlings was placed in the greenhouse among those exposed in the field as controls. The low levels of greasy spot occurring on these plants were subtracted from the trap-plant readings made within 3 months of the rating date on the controls.

Leaf litter. The amount and degree of decomposition of the leaf litter under the test trees were evaluated every 2 weeks. Fallen leaves were sampled by placing a 30-cm-square plastic frame arbitrarily beneath the canopy of each test tree in three locations at each observation time. All the leaves in each frame were counted and grouped in one of three categories: $1=$ preproducing, i.e., leaves recently fallen,

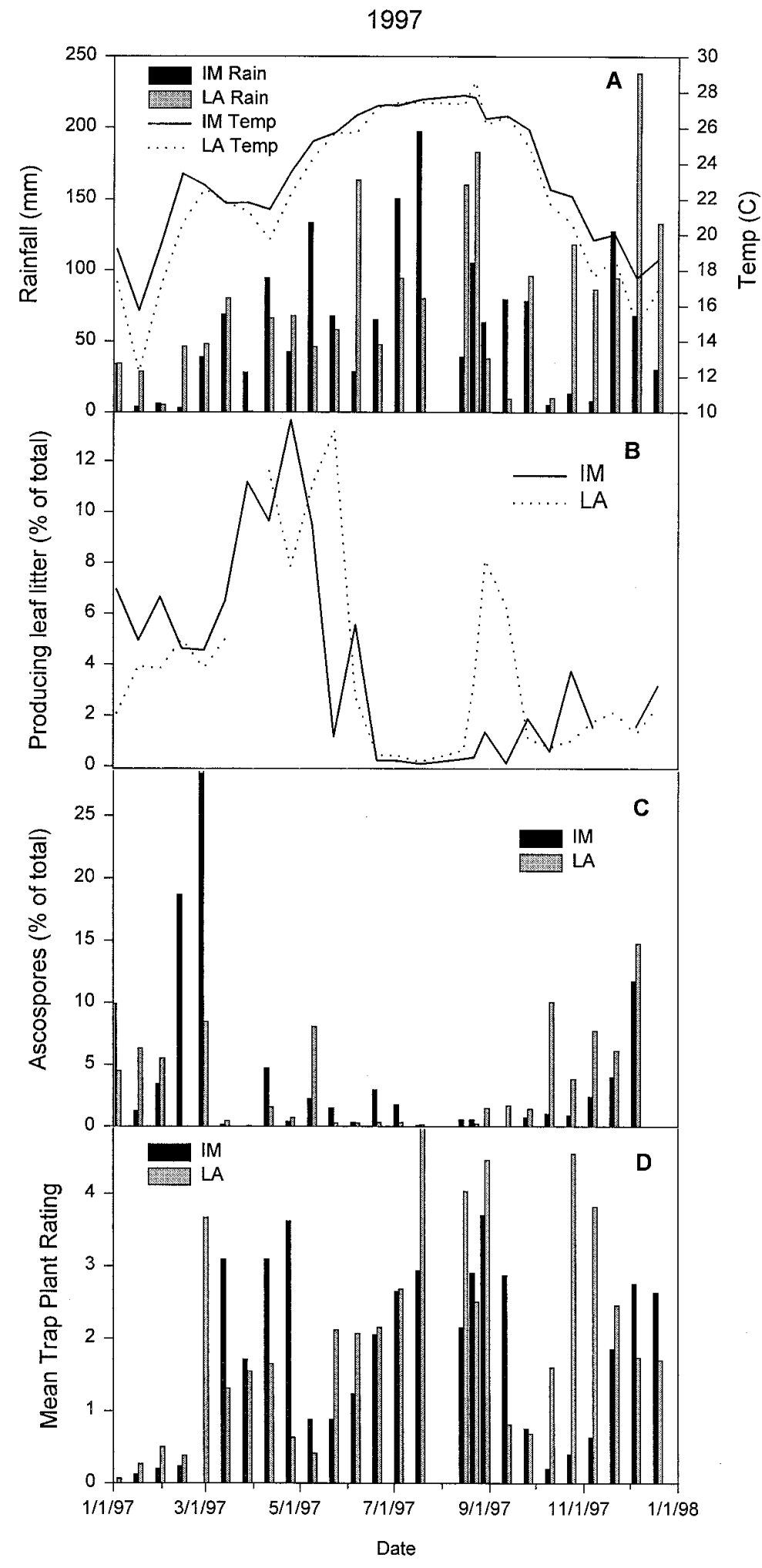

Fig. 1. Rainfall and average temperature, amount of leaf litter under trees, numbers of ascospores of Mycosphaerella citri captured, and severity of greasy spot on trap plants in Immokalee (IM, southwest Florida) and in Lake Alfred (LA, central Florida) in 1997. (A) Total rainfall and average temperature for each 2-week period; (B) leaves on grove floor in a stage capable of producing ascospores as percentage of those leaves for entire year; (C) number of ascospores captured in each 2-week period as percentage of total ascospores per year; (D) mean greasy spot rating on a scale of 0 to 6 on rough lemon trap plants exposed for 2 weeks in groves in Lake Alfred and Immokalee. 
1998

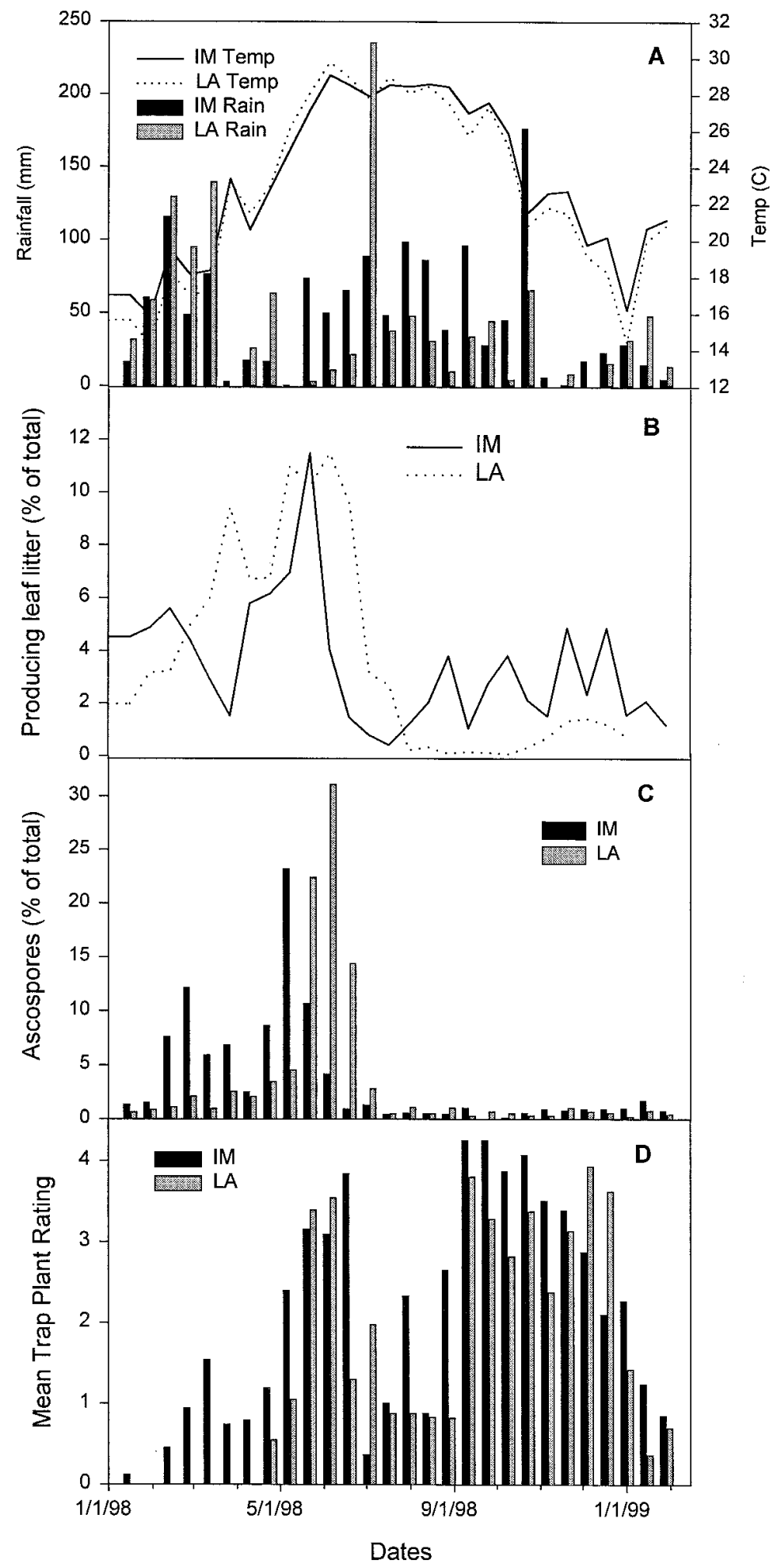

Fig. 2. Rainfall and average temperature, amount of leaf litter under trees, numbers of ascospores of Mycosphaerella citri captured, and severity of greasy spot on trap plants in Immokalee (IM, southwest Florida) and in Lake Alfred (LA, central Florida) in 1998. (A) Total rainfall and average temperature for each 2-week period; (B) leaves on grove floor in a stage capable of producing ascospores as percentage of those leaves for the entire year; (C) number of ascospores captured in each 2-week period as percentage of total ascospores per year; (D) mean greasy spot rating on a scale of 0 to 6 on rough lemon trap plants exposed for 2 weeks in groves in Lake Alfred and Immokalee. not decomposed; 2 = partially decomposed leaves with pseudothecia present; and $3=$ postproducing, highly decomposed and skeletonized leaves that probably were no longer producing ascospores. Leaves considered to be in the ascospore-producing stage (group 2) are presented as percentage of the total leaves in that category for the year.

Ascospore counts. A 7-day recording volumetric spore sampler was operated continuously at each site during the study period. The samplers were modifications of those of Gadoury and MacHardy (2) and were designed to be more sturdy to withstand conditions of year-long exposure in a citrus grove. The samplers were designed and built by T. R. Gottwald (USDA, Ft. Pierce, FL) as described by Timmer et al. (7) and functioned in the same manner as the Gadoury-MacHardy sampler and the Burkard volumetric spore sampler (Burkard Scientific Sales, Ltd., Rickmansworth, Hertfordshire, UK). The spore trap tapes were coated first with a base layer of gelvitol (35 g), glycerol $(50 \mathrm{ml})$, phenol (2 $\mathrm{g})$, and distilled water $(100 \mathrm{ml})$. This was followed by a second layer consisting of petroleum gel $(25 \mathrm{~g})$, paraffin wax (12 g), and toluene (about $50 \mathrm{ml}$; the amount was reduced in summer when field temperatures were higher). The 7-day tapes were removed from the drum, cut into 1-day segments, mounted on microscope slides, stained with cotton blue-lactophenol, and covered with a cover slip. Ascospores of $M$. citri were counted in a single pass across each microscope slide at $\times 400$ magnification, and the total number for each 2week period was recorded. Data were expressed as the percentage of the total observed ascospores for each year at each location.

Environmental variables. Daily rainfall totals and average daily temperatures were recorded by automated weather stations located at both sites. Stations were within $500 \mathrm{~m}$ of the test trees.

Spray timing. Spray timing trials were established in the central Florida, east coast, and southwest Florida production areas in the 1998-99 and 1999-2000 seasons to assess the influence of regional differences in greasy spot epidemiology. Experiments were conducted in a Marsh White grapefruit grove near Lake Alfred in central Florida, in a Marsh White grove near LaBelle in southwest Florida, and in a Ruby Red grapefruit grove near Ft. Pierce in the east coast production area. During the 1998-99 season, each treatment consisted of a single copper fungicide application made between 10 and 20 April, May, June, July, or August and was compared with a nonsprayed control. In the 19992000 season, two two-spray treatments, May + July and June + August, were also included at all three locations.

Experimental plots consisted of three trees in a row with an unsprayed guard tree 
between plots. At the Ft. Pierce location in 1999-2000, two-tree plots were used. An unsprayed guard row was left between each two rows of treated trees in all locations. Each treatment was replicated five times, and treatments were arranged in a randomized complete block design. Fungicide was applied with an airblast sprayer utilizing 1,200 liters/ha in Lake Alfred, 2,400 liters/ha in Ft. Pierce, and 1,800 liters/ha in LaBelle. The fungicide used in all tests was copper hydroxide (Kocide 2000, 35\% metallic copper) and was applied at $5.6 \mathrm{~kg} / \mathrm{ha}$ except at Lake Alfred in 1998-99, where it was applied at 11.2 $\mathrm{kg} / \mathrm{ha}$, and in Ft. Pierce, where it was applied at $9.3 \mathrm{~kg} / \mathrm{ha}$ in the $1999-2000$ season.

In April of each year, shoots from the spring flush of growth were tagged for later disease evaluation. In most cases, 10 shoots with 4 to 12 leaves per shoot were tagged on each tree in each year. In Ft. Pierce in 1999-2000, 15 shoots per tree were tagged. Greasy spot severity was evaluated from late November to the end of January each season following the previous summer's fungicide applications. Greasy spot severity on each shoot was rated on a scale of 1 to 6 as described for the greenhouse evaluations. The percentage of defoliation was calculated for all of the shoots on each tree. Mean severity ratings and defoliation percentages were calculated for each tree and then for each replicate plot. Data were normally distributed. Plot means were subjected to analysis of variance and means separated by the Waller-Duncan $k$-ratio $t$ test, $P \leq$ 0.05 .

\section{RESULTS}

Epidemiological studies. 1997. Freezing temperatures that occurred in January 1997 in Immokalee, but not in Lake Alfred, induced early leaf drop in Immokalee (Fig. 1). These leaves produced a large crop of ascospores in early March in Immokalee. Large amounts of leaf litter were present through June in both locations. Leaf litter was virtually absent in July and August, but some accumulated again in the fall and early winter. Disease severity was low on trap plants exposed in January and February 1997 at both locations. Disease severity on trap plants exposed during the remainder of the year was moderate to high, but variable. Disease severity was high after exposure in summer and early fall despite the low numbers of ascospores captured. The pattern of disease severity on trap plants followed the rainfall pattern more closely than the pattern of ascospore release. Average winter temperatures were higher in Immokalee than in Lake Alfred (Fig. 1).

1998. The ascospore-producing leaf litter in Lake Alfred was concentrated in the March to July period (Fig. 2). Leaf litter in Immokalee was most abundant in late spring and early summer, but more litter was present in the fall in Immokalee than in Lake Alfred. Most of the ascospores were captured from February to June in Immokalee, with only low numbers thereafter. In Lake Alfred, the ascospore peak occurred in June and July, with few spores after that time. Although there were peaks in disease severity on trap plants that corresponded to the peaks in ascospore production, disease was very severe again late in the year when ascospore production was low. In spite of fairly high rainfall early in the year, disease severity was low on trap plants exposed at this time, especially in Lake Alfred. Winter temperatures were again higher in Immokalee than in Lake Alfred in 1998

Spray timing. In Lake Alfred, a single copper fungicide spray applied in May provided the best control in 1998-99 (Table 1). June or July applications were equally good, but April or August applications were less effective. All treatments reduced disease severity and defoliation. In the 1999-2000 season, any of the single-spray treatments from May to August reduced disease severity, but a single spray in April did not significantly reduce disease. Twospray treatments, either May + July or June + August, were highly effective in controlling the disease. None of the treatments significantly reduced defoliation.
In LaBelle in 1998-99, disease severity was high. The only single-spray treatment that reduced disease was the May application, and none of the treatments reduced defoliation (Table 1). In 1999-2000, the June or July sprays reduced disease severity and defoliation. The two-spray treatments, May + July or June + August, were no more effective than single sprays in June or July.

In Ft. Pierce in 1998-99, all single-spray treatments from April to August reduced disease severity and defoliation, and none was any better than any other (Table 1). In 1999-2000, the single spray in June reduced disease severity more than any other single-spray treatment. The May or July single-spray applications provided better control than the April or August singlespray treatments. The June + August twospray treatment was very effective in reducing disease severity but was still no more effective than a single spray in June. Defoliation generally followed the same pattern as disease severity, but only the June + August treatment significantly reduced defoliation compared with the nonsprayed control.

\section{DISCUSSION}

Greasy spot in Florida under current conditions is a disease with many overlapping cycles per year, in contrast to the previous situation when the disease was essentially monocyclic (8). Ascospore production occurs year-round in Florida, and conditions are adequate for at least some infection virtually any time of year. Each cycle, however, requires 8 to 12 months to complete. In Costa Rica, ascospore production is concentrated in a very short period at the beginning of the rainy season in May and June, and greasy spot was thought to be a monocyclic disease there as well (3). However, more recent studies indicate that considerable infection can occur at other times of the year (1).

Differences in inoculum production at different times of the year do not result in differences in disease severity. Even when inoculum levels were low, the amount of

Table 1. Effect of time of application of a copper fungicide on greasy spot severity and defoliation of the spring growth flush of grapefruit in central Florida (Lake Alfred), southwest Florida (LaBelle), and on the east coast (Ft. Pierce)

\begin{tabular}{|c|c|c|c|c|c|c|c|c|c|c|c|c|}
\hline \multirow[b]{3}{*}{$\begin{array}{l}\text { Time of } \\
\text { application }\end{array}$} & \multicolumn{4}{|c|}{ Lake Alfred } & \multicolumn{4}{|c|}{ LaBelle } & \multicolumn{4}{|c|}{ Ft. Pierce } \\
\hline & \multicolumn{2}{|c|}{ 1998-99 } & \multicolumn{2}{|c|}{ 1999-2000 } & \multicolumn{2}{|c|}{ 1998-99 } & \multicolumn{2}{|c|}{ 1999-2000 } & \multicolumn{2}{|c|}{ 1998-99 } & \multicolumn{2}{|c|}{ 1999-2000 } \\
\hline & $\begin{array}{c}\text { Severity } \\
(0-5)\end{array}$ & $\begin{array}{l}\text { Defolia- } \\
\text { tion (\%) }\end{array}$ & $\begin{array}{c}\text { Severity } \\
(0-5)\end{array}$ & $\begin{array}{l}\text { Defolia- } \\
\text { tion }(\%)\end{array}$ & $\begin{array}{c}\text { Severity } \\
(0-5)\end{array}$ & $\begin{array}{l}\text { Defolia- } \\
\text { tion (\%) }\end{array}$ & $\begin{array}{c}\text { Severity } \\
(0-5)\end{array}$ & $\begin{array}{l}\text { Defolia- } \\
\text { tion }(\%)\end{array}$ & $\begin{array}{c}\text { Severity } \\
(0-5)\end{array}$ & $\begin{array}{l}\text { Defolia- } \\
\text { tion }(\%)\end{array}$ & $\begin{array}{c}\text { Severity } \\
(0-5)\end{array}$ & $\begin{array}{l}\text { Defolia- } \\
\text { tion (\%) }\end{array}$ \\
\hline None & $1.44 \mathrm{a}^{\mathrm{z}}$ & $10.6 \mathrm{a}$ & $0.85 \mathrm{a}$ & $6.5 \mathrm{ab}$ & $1.7 \mathrm{a}$ & 7.3 & $1.27 \mathrm{ab}$ & $20.4 \mathrm{ab}$ & $0.98 \mathrm{a}$ & $10.9 \mathrm{a}$ & $1.65 \mathrm{ab}$ & $27.8 \mathrm{ab}$ \\
\hline Apr & $0.74 \mathrm{~b}$ & $4.3 \mathrm{bc}$ & $0.71 \mathrm{ab}$ & $14.4 \mathrm{a}$ & $1.6 \mathrm{ab}$ & 4.7 & $1.38 \mathrm{a}$ & $23.4 \mathrm{ab}$ & $0.44 \mathrm{c}$ & $2.4 \mathrm{~b}$ & $1.82 \mathrm{a}$ & $26.4 \mathrm{ab}$ \\
\hline May & $0.24 \mathrm{e}$ & $1.2 \mathrm{c}$ & $0.54 \mathrm{bc}$ & $8.2 \mathrm{ab}$ & $1.1 \mathrm{~b}$ & 2.7 & $1.02 \mathrm{abc}$ & $17.4 \mathrm{abc}$ & $0.65 \mathrm{~b}$ & $4.1 \mathrm{~b}$ & $1.19 \mathrm{~b}$ & $18.2 \mathrm{abc}$ \\
\hline Jun & $0.50 \mathrm{~cd}$ & $5.7 \mathrm{~b}$ & $0.41 \mathrm{c}$ & $10.1 \mathrm{ab}$ & $1.3 \mathrm{ab}$ & 2.1 & $0.71 \mathrm{~cd}$ & $7.0 \mathrm{c}$ & $0.48 \mathrm{bc}$ & $3.3 \mathrm{~b}$ & $0.22 \mathrm{c}$ & $10.6 \mathrm{bc}$ \\
\hline Jul & $0.37 \mathrm{de}$ & $1.9 \mathrm{bc}$ & $0.32 \mathrm{~cd}$ & $3.0 \mathrm{~b}$ & $1.6 \mathrm{ab}$ & 2.5 & $0.78 \mathrm{~cd}$ & $13.8 \mathrm{bc}$ & $0.42 \mathrm{c}$ & $4.5 \mathrm{~b}$ & $1.27 \mathrm{~b}$ & $20.8 \mathrm{abc}$ \\
\hline Aug & $0.66 \mathrm{bc}$ & $4.1 \mathrm{bc}$ & $0.39 \mathrm{c}$ & $7.6 \mathrm{ab}$ & $1.3 \mathrm{ab}$ & 2.8 & $1.05 \mathrm{abc}$ & $15.8 \mathrm{abc}$ & $0.47 \mathrm{bc}$ & $3.0 \mathrm{~b}$ & $1.70 \mathrm{ab}$ & $37.0 \mathrm{a}$ \\
\hline May + Jul & $\ldots$ & $\ldots$ & $0.10 \mathrm{de}$ & $4.9 \mathrm{~b}$ & $\ldots$ & $\ldots$ & $0.90 \mathrm{bcd}$ & $28.2 \mathrm{a}$ & $\ldots$ & $\ldots$ & $0.58 \mathrm{c}$ & $15.2 \mathrm{bc}$ \\
\hline Jun + Aug & $\ldots$ & $\ldots$ & $0.08 \mathrm{e}$ & $4.7 \mathrm{~b}$ & $\ldots$ & $\ldots$ & $0.58 \mathrm{~d}$ & $18.2 \mathrm{abc}$ & $\ldots$ & $\ldots$ & $0.09 \mathrm{c}$ & $6.0 \mathrm{c}$ \\
\hline & & & & & & NS & & & & & & \\
\hline
\end{tabular}

${ }^{\mathrm{z}}$ Numbers in columns followed by the same letter are not significantly different. Mean separation by Waller-Duncan $k$-ratio $t$ test, $P \leq 0.05$. 
infection that occurred on trap plants was high when environmental conditions were favorable. We suggest that hyphae produced by the few ascospores deposited on the undersurface of the leaf proliferate epiphytically and result in considerable infection. In the spring, the weather is dry and conditions are less favorable for epiphytic development. However, there are large numbers of ascospores available, and high levels of infection can still occur. Thus, measures taken to reduce inoculum as suggested previously (5) would probably be effective only in the dry periods of the year. Increasing leaf decomposition by additional irrigation and nitrogen fertilization or by covering decomposing leaves with mulch might reduce inoculum in the spring and shorten the period of the year in which infection occurs. Adopting such measures when environmental conditions are favorable would be less likely to be effective. At present, the only environmental factor that appears to reduce infection is low temperature in winter. Temperatures below $20^{\circ} \mathrm{C}$ greatly reduce development of greasy spot and defoliation $(10,13)$. In Texas, where prolonged cool temperatures in winter resulted in delayed symptom development and defoliation, greasy spot did not affect yields (6).

Some differences between greasy spot development in central and southwest Florida noted in this study were observed previously (5). Leaf litter, ascospore production, and infection appear to be slightly more concentrated in the late spring to fall in central Florida. In southwest Florida, the season for infection appears to be longer, with more infection earlier in the spring and later in the fall. Winter temperatures and rainfall are higher in southwest Florida, which increases the amount of infection and speeds symptom development. Thus, the disease may be more difficult to control in that area (5).
Previous work indicated that the optimum time for single-spray copper treatments was June or July in central Florida (14). April and May applications were less effective. Russo and Bistline (4) reached similar conclusions, but found that applications in April, May, or August occasionally were more effective. In the current study, the optimum timing varied with year and location. A June application was generally more effective than a single application in any other month. An application at this time apparently is early enough to kill epiphytic mycelium before it penetrates and late enough to protect against infections for most of the summer rainy season. In 1999-2000, a two-spray program was not always more effective than a well-timed single-spray treatment; however, we investigated only the disease effects on the spring flush of growth.

Greasy spot is more severe in southwest Florida and in the east coast area than in central Florida (5). The disease cycle varies somewhat with location, but probably not enough to greatly affect management strategies. Greasy spot is more severe in southern and eastern areas, most likely because of higher rainfall and warmer temperatures. Two-spray programs increase the probability that at least one of the treatments will be properly timed and also have the advantage of controlling the disease on summer flushes.

\section{ACKNOWLEDGMENTS}

This investigation was supported in part by the Florida Citrus Production Research Advisory Council Project 961-04. We gratefully acknowledge the technical assistance of Turksen Kamber, Frankie Ligas, Aaron Hert, and Jennifer Parsons.

\section{LITERATURE CITED}

1. Brenes, I. L. 1999. Manejo fitosanitario de la naranja: Bases para un uso racional de plaguicidas con especial énfasis en el control de la mancha grasienta. M.S. thesis. University of Costa Rica, San Jose.
2. Gadoury, D. M., and MacHardy, W. E. 1983 A 7-day recording volumetric spore trap. Phytopathology 73:1526-1531.

3. Hidalgo, H., Sutton, T. B., and Arauz, F. 1997. Epidemiology and control of citrus greasy spot on Valencia orange in the humid tropics of Costa Rica. Plant Dis. 81:10151022.

4. Russo, L. W., and Bistline, F. W. 1992. Results from a thirteen year study to study effective spray timing with greasy spot (Mycosphaerella citri) spore populations on east coast and ridge area groves. Proc. Fla. State Hortic. Soc. 105:19-20.

5. Timmer, L. W., Gottwald, T. R., McGovern, R. J., and Zitko, S. E. 1995. Time of ascospore release and infection by $M y$ cosphaerella citri in central and southwest Florida. Proc. Fla. State Hortic. Soc. 108: 374-377.

6. Timmer, L. W., Reeve, R. J., and Davis, R. M. 1980. Epidemiology and control of citrus greasy spot on grapefruit in Texas. Phytopathology 70:863-867.

7. Timmer, L. W., Solel, Z., Gottwald, T. R., Ibáñez, A. M., and Zitko, S. E. 1998. Environmental factors affecting production, release, and field populations of conidia of $\mathrm{Al}$ ternaria alternata, the cause of brown spot of citrus. Phytopathology 88:1218-1223.

8. Whiteside, J. O. 1970. Etiology and epidemiology of citrus greasy spot. Phytopathology 60:1409-1414.

9. Whiteside, J. O. 1972. Effectiveness of spray materials against citrus greasy spot in relation to time of application and infection periods. Proc. Fla. State Hortic. Soc. 84:56-63.

10. Whiteside, J. O. 1974. Environmental factors affecting infection of citrus leaves by $M y$ cosphaerella citri. Phytopathology 64:115120.

11. Whiteside, J. O. 1976. Epidemiology and control of greasy spot, melanose, and scab in Florida citrus groves. PANS 22:243-249.

12. Whiteside, J. O. 1981. Diagnosis of citrus greasy spot based on experiences with this disease in Florida. Proc. Int. Soc. Citric. 2:336-340.

13. Whiteside, J. O. 1982. Effect of temperature on the development of citrus greasy spot. Proc. Fla. State Hortic. Soc. 95:66-68.

14. Whiteside, J. O. 1982. Timing of single-spray treatments for optimal control of greasy spot on grapefruit leaves and fruit. Plant Dis. 66:687-690. 